\title{
INTERVENSI PSIKOLOGIS PADA PENDIDIKAN ANAK DENGAN KETERLAMBATAN BICARA
}

\author{
Zainal Habib \\ Dosen Fakultas Psikologi UIN Maulana Malik Ibrahim Malang \\ Laily Hidayati \\ Dosen Sekolah Tinggi Agama Islam (STAI) at-Tanwir Bojonegoro
}

\begin{abstract}
s
As the ability to ride a bike, speech is a child's ability to learn. The more frequent practice, these abilities will be more perfect. Many factors affect the process of learning or practice speaking. Among others is the maturity or physical and mental readiness, a good model to be emulated, the motivation they need, the opportunities provided by the environment, and the existence guidance of significant others. Then, how to help children who have spent time to learn speech and due to several factors as mentioned above, have experienced delays in speech?. Excavation data about the causes of overdue talking to children, followed by the deepening problems in a mature, will find the steps that can be taken to help overdue talking children in speech.
\end{abstract}

Keywords: Development of Speech, Parenting Education, Interventions Overdue Talking

\section{A. Pendahuluan}

Dalam kajian perkembangan anak, perkembangan bicara biasanya diidentikkan dengan perkembangan bahasa. Padahal sebenarnya kedua hal tersebut secara istilah tidaklah sama. Bahasa menunjuk pada setiap sarana komunikasi dengan menyimbolkan pikiran dan perasaan untuk menyampaikan makna kepada orang lain. Di dalamnya meliputi tulisan, bicara, bahasa simbol, ekspresi muka, isyarat, pantomim, dan seni. Sedangkan bicara menunjuk pada bentuk bahasa yang menggunakan artikulasi atau kata-kata yang digunakan untuk menyampaikan maksud. Karena bicara merupakan bentuk komunikasi yang paling efektif, maka penggunaannya pun paling luas dan paling penting (Hurlock, 1978: 176).

Berbicara tidak hanya melibatkan koordinasi kumpulan otot mekanisme suara yang berbeda, melainkan juga menyangkut aspek mental yakni kemampuan mengaitkan arti dengan bunyi yang dihasilkan. Sehingga kemampuan berbicara pada dasarnya merupakan kemampuan mental-motorik. Meskipun demikian, tidak semua bunyi yang dibuat atau dihasilkan oleh seorang anak dapat dikatakan sebuah bicara. 
Sebelum seorang anak dapat menghasilkan bunyi yang jelas, berbeda, dan terkendali, sebagai akibat kemampuan pengendalian mekanisme otot syaraf penghasil bunyi, maka hal tersebut hanya disebut sebagai bunyi artikulasi dan bukan sebuah proses bicara. Inilah yang disebut dengan "membeo" pada masyarakat kita.

Mengapa kemampuan bicara menjadi sangat penting dalam kehidupan seseorang bahkan semenjak ia masih kecil, adalah dikarenakan beberapa hal berikut:

1. Sebagai sarana pemuasan kebutuhan dan keinginan.

2. Merupakan salah satu alat penarik perhatian orang lain pada diri individu.

3. Menjadi alat untuk menjalin hubungan sosial.

4. Menjadi patokan penilaian sosial seperti latar belakang sosial, asal-usul ras, kelayakan kelamin, dll.

5. Menjadi salah satu rujukan penilaian diri ketika individu mendapatkan penilaian dari orang lain tentang kemampuan bicaranya.

6. Terdapat dalam penilaian prestasi akademik.

7. Berpengaruh terhadap pikiran, perasaan serta perilaku orang lain.

Mengingat peran perkembangan kemampuan bicara pada individu yang sangat penting, akan menjadi menarik untuk mengkaji perkembangan kemampuan bicara pada seorang anak dengan keterlambatan berbicara. Apa penyebabnya, faktor apa yang mungkin berpengaruh dan memperparah keterlambatan tersebut, bagaimana intervensinya, serta mengapa intervensi tersebut dipilih untuk mengatasi kasus tertentu dalam keterlambatan berbicara.

\section{B. Pola Asuh dan Perkembangan Bicara Pada Anak}

\section{Teori Pola Asuh}

Gaya konseptual pola asuh Baumrind didasarkan pada pendekatan tipologis pada studi praktek sosialisasi keluarga. Pendekatan ini berfokus pada konfigurasi dari praktek pola asuh yang berbeda dan asumsi bahwa akibat dari salah satu praktek tersebut tergantung sebagian pada pengaturan kesemuanya. Variasi dari konfigurasi elemen utama pola asuh (seperti kehangatan, keterlibatan, tuntutan kematangan, dan supervisi) menghasilkan variasi dalam bagaimana seorang anak merespon pengaruh orangtua. Dari perspektif ini, gaya pola asuh dipandang sebagai karakteristik orang tua yang membedakan 
keefektifan dari praktek sosialisasi keluarga dan penerimaan anak pada praktek tersebut.

Tipologi gaya pola asuh Baumrind (1971) mengidentifikasi tiga pola yang berbeda secara kualitatif pada otoritas orangtua, yaitu authoritarian parenting, authoritative parenting dan permisive parenting. Tipologi ini menggolongkan keluarga berdasarkan tingkat tuntutan orangtua (kontrol, supervisi, tuntutan kematangan) dan tanggapan (kehangatan, penerimaan, keterlibatan). Perbedaan utama antara gaya Baumrind dan Maccoby \& Martin adalah Maccoby \& Martin membedakan dua tipe pada pola asuh permisif. Dengan demikian kebiasaan cara/gaya orang tua ketika mereka berinteraksi dengan anak-anaknya merupakan dimensi pola asuh yang penting. Perkembangan mentalitas anak memiliki proses pencarian yang panjang bagi orang tua untuk meningkatkan kemampuan perkembangan sosio-emosional. Sebagai contoh, pada tahun 1930-an, John Watson berpendapat bahwa orang tua terlalu menyayangi anaknya. Pada tahun 1950-an, suatu perbedaan terjadi antara ilmu fisik dan psikologi. Ilmu psikologi, khususnya alasan atau motivasi yang ditekankan sebagai cara yang terbaik untuk membesarkan seorang anak. Pada tahun 1970-an dan sesudahnya, suatu pandangan kemampuan pola asuh orang tua yang telah menjadi lebih tepat. Orang tua seharusnya tidak menghukum atau menarik diri, tetapi mereka seharusnya mengembangkan peraturanperaturan untuk anak-anak dan menyayangi mereka.

\section{a) Pola asuh autoritarian (Authoritarian parenting style)}

Pola asuh orangtua yang autoritarian adalah orangtua yang memberikan batasan-batasan tertentu dan aturan yang tegas terhadap anaknya, tetapi memiliki komunikasi verbal yang rendah. Pola asuh ini merupakan cara yang membatasi dan bersifat menghukum sehingga anak harus mengikuti petunjuk orangtua dan menghormati pekerjaan dan usaha orangtua. Contoh orangtua yang authoritarian akan berkata : "Kamu melakukan hal itu sesuai dengan cara saya atau orang lain“. Dalam hal ini nampak sekali orangtua bersikap kaku dan banyak menghukum anak-anak mereka yang melanggar, karena sikap otoriter orangtua. Biasanya pola asuh ini memiliki kontrol yang kuat, sedikit komunikasi, membatasi ruang gerak anak, dan berorientasi pada hukuman fisik maupun verbal agar anak patuh 
dan taat. Ada ketakutan yang tinggi dalam diri orangtua terhadap anaknya karena adanya pertentangan dalam kemauan dan keinginan. Jadi anakanak ini sering sekali tidak bahagia, ketakutan dan cemas dibandingkan dengan anak lain, gagal memulai suatu kegiatan, menarik diri karena tidak puas diri dan memiliki ketrampilan komunikasi yang lemah.

b) Pola asuh permisif (Permisive parenting style) .

Pola asuh permisif menekankan ekspresi diri dan self regulation anak. Orangtua yang permisif membuat beberapa aturan dan mengijinkan anakanaknya untuk memonitor kegiatan mereka sebanyak mungkin. Ketika mereka membuat peraturan biasanya mereka menjelaskan alasan dahulu, orang tua berkonsultasi dengan anak tentang keputusan yang diambil dan jarang menghukum. Tipologi ini karena adanya tingkat tuntutan orang tua dan tanggapan yang ada. Dengan demikian pola asuh permisif terdiri dari dua jenis yaitu :

1) Pola asuh permisif yang penuh kelalaian (Permisive-neglectfull parenting).

Pada pola ini orangtua sangat tidak ikut campur dalam kehidupan anaknya. Orangtua yang seperti ini tidak akan pernah tahu keberadaan anak mereka dan tidak cakap secara sosial, padahal anak membutuhkan perhatian orang tua ketika mereka melakukan sesuatu. Anak ini biasanya memiliki self esteem yang rendah, tidak dewasa dan diasingkan dalam keluarga. Pada masa remaja mereka mengalami penyimpanganpenyimpangan perilaku, misalnya suka tidak masuk sekolah, kenakalan remaja. Dengan demikian anak menunjukkan pengendalian diri yang buruk dan tidak bisa menangani kebebasan dengan baik. Jadi orangtua yang tidak menuntut ataupun menanggapi menunjukkan suatu pola asuh yang neglectful atau uninvolved. Orangtua ini tidak memonitor perilaku anaknya ataupun mendukung ketertarikan mereka, karena orang tua sibuk dengan masalahnya sendiri dan cenderung meninggalkan tanggung jawab mereka sebagai orang tua.

2) Pengasuhan permisif yang Pemurah (Permisive-indulgent parenting).

Pada pola ini orangtua sangat terlibat dengan anaknya tetapi sedikit sekali menuntut atau mengendalikan mereka. Biasanya orangtua yang 
demikian akan memanjakan, dan mengizinkan anak untuk melakukan apa saja yang mereka inginkan. Gaya pola asuh ini menunjukkan bagaimana orangtua sangat terlibat dengan anaknya, tetapi menempatkan sedikit sekali kontrol pada mereka. Hal ini berkaitan dengan ketidakmampuan sosial, terutama dalam kontrol diri. Jadi gaya pola asuh permisif indulgent, orangtua memiliki tuntutan rendah dan tanggapan terlibat tinggi pada anak. Orangtua ini toleran, hangat dan menerima. Mereka menunjukkan sedikit otoritas, dan membiarkan terbentuknya self-regulation pada anak atau remaja.

Pola asuh permisif mengutamakan kebebasan, dan anak diberikan kebebasan penuh untuk mengungkapkan keinginan dan kemauannya dalam memilih. Pada dasarnya orangtua dalam pola ini akan menuruti kehendak anak, dan kerangka pemikiran psikoanalitis melandasi pandangan orangtua yang memandang bahwa setiap manusia dilahirkan sudah memiliki kebutuhan dasar pribadi yang menuntut untuk dipenuhi. Oleh karena itu apabila tuntutan ini tidak dipenuhi maka akan terjadi halangan perkembangan dan timbul penyimpangan dalam pertumbuhan dan perkembangan anak. Oleh karena itu anak harus diberikan kebebasan penuh serta dihindari penekanan terhadap keinginan dan kemauan anak, dan dibiarkan berkembang dengan apa adanya. Pandangan liberal ini berkembang di Inggris, yang dikembangkan oleh Neill (1960), dia menyarankan supaya anak sebaiknya diberikan kebebasan penuh untuk melakukan apa yang menjadi keinginannya. Jika anak berbuat kesalahan, maka orang tua tidak perlu ikut serta untuk memperbaikinya tetapi cukup hanya membiarkan saja supaya anak itu memperbaiki sendiri dirinya sendiri. Faham ini memandang bahwa seorang anak secara alamiah telah memiliki suatu kemampuan untuk dapat mengurus dan mengatur dirinya sendiri, sehingga orang lain tidak perlu ikut campur tangan. Dari perkembangan liberal yang ada kemudian berkembang konsep baru dari Rogers dimana menyarankan supaya anak diasuh dengan campur tangan yang sesedikit mungkin dari orang tua maupun dari lingkungan. 
Pola asuh orang tua permisif bersikap terlalu lunak, tidak berdaya, memberi kebebasan terhadap anak tanpa adanya norma-norma yang harus diikuti oleh mereka. Mungkin karena orang tua sangat sayang (over affection) terhadap anak atau orangtua kurang dalam pengetahuannya. Pola asuh demikian ditandai dengan nurturance yang tinggi, namun rendah dalam tuntutan kedewasaan, kontrol dan komunikasi, cenderung membebaskan anak tanpa batas, tidak mengendalikan anak, lemah dalam keteraturan hidup, dan tidak memberikan hukuman apabila anak melakukan kesalahan, dan tidak memiliki standart bagi perilaku anak, serta hanya memberikan sedikit perhatian dalam membina kemandirian dan kepercayaan diri anak.

\section{c) Pola asuh autoritatif (Autoritative Parenting style)}

Pola asuh yang bergaya autoritatif mendorong anak untuk bebas tetapi tetap memberikan batasan dan mengendalikan tindakan-tindakan mereka. Adanya sikap orangtua yang hangat dan bersifat membesarkan hati anak, dan komunikasi dua arah yang bebas membuat anak semakin sadar dan bertanggung jawab secara sosial. Hal ini disebabkan karena orang tua dapat merangkul dan mencarikan alasan untuk solusi di masa depan. Contoh sikap orangtua yang autoritative : "Kamu tahu bahwa kamu seharusnya tidak melakukan hal itu, tetapi sekarang mari kita diskusikan bersama bagaimana kita bisa mengatasi situasi tersebut dengan lebih baik di masa depan". Sebenarnya pola asuh ini merupakan gabungan dari kedua pola asuh yaitu pola asuh autoritarian dan permisif.

Dalam pola asuh ini dipandang bahwa kebebasan pribadi untuk memenuhi keinginan dan kebutuhannya baru bisa tercapai dengan sempurna apabila anak mampu mengontrol dan mengendalikan diri serta menyesuaikan diri dengan lingkungan baik keluarga dan masyarakat. Dalam hal ini anak diberi kebebasan namun dituntut untuk mampu mengatur dan mengendalikan diri serta menyesuaikan diri dan keinginannya dengan tuntutan lingkungan. Oleh karena itu sebelum anak mampu mengatur dan mengendalikan dirinya sendiri, maka dalam dirinya perlu ditumbuhkan perangkat aturan sebagai alat kontrol yang dapat mengatur dan mengendalikan dirinya sesuai dengan aturan yang berlaku di lingkungannya. Pengontrolan dalam hal ini, walaupun dalam 
bentuk apapun hendaknya selalu ditujukan supaya anak memiliki sikap bertanggung jawab terhadap dirinya sendiri dan terhadap lingkungan masyarakat.

Dengan demikian, anak akan memiliki otonomi untuk melakukan pilihan dan keputusan yang bernilai bagi dirinya sendiri dan bagi lingkungannya. Dalam hal ini perlu disadari bahwa kontrol yang ketat harus diimbangi dengan dorongan kuat yang positif agar individu tidak hanya merasa tertekan tetapi juga dihargai sebagai pribadi yang bebas. Komunikasi antara orang tua dengan anak atau anak dengan orang tua dan aturan intern keluarga merupakan hasil dari kesepakatan yang telah disetujui dan dimengerti bersama. Untuk hal ini Baumrind (1978) menekankan bahwa dalam pengasuhan autoritatif mengandung beberapa prinsip sebagai berikut:

1) Kebebasan dan pengendalian merupakan prinsip yang saling mengisi, dan bukan suatu pertentangan.

2) Hubungan orang tua dengan anak memiliki fungsi bagi orang tua dan anak.

3) Adanya kontrol yang diimbangi dengan pemberian dukungan dan semangat.

4) Adanya tujuan yang ingin dicapai yaitu kemandirian, sikap bertanggung jawab terhadap diri sendiri dan tanggung jawab terhadap lingkungan masyarakat.

\section{Teori Perkembangan Bicara Anak}

Bicara merupakan sebuah keterampilan, dan seperti halnya keterampilan yang lain, ia harus dipelajari. Komponen kemampuan berbicara sendiri terdiri atas dua hal. Pertama, adalah kemampuan mengeluarkan bunyi tertentu dalam kombinasi yang dikenal sebagai kata, yakni aspek motorik bicara. Kedua, kemampuan mengaitkan arti dengan kata-kata tersebut, yakni aspek mental dari bicara. Diperlukan adanya koordinasi otot untuk menghasilkan kombinasi suara yang dikenal dengan kata, tingkat ksulitannya akan sama dengan keharusan praktek belajar yang membutuhkan waktu yang tidak sebentar. Dan lebih lanjut, keharusan dalam kemampuan mengaitkan arti dengan kata dan mempelajari tata bahasa akan menambah tingkat kesulitan dalam belajar keterampilan berbicara. 
Belajar berbicara mencakup tiga proses terpisah akan tetapi saing berhubungan satu sama lain, yakni belajar mengucapkan kata, membangun kosa kata, dan membentuk kalimat. Karena ketiga proses tersebut saling berkaitan, maka kegagalan mempelajari salah satunya akan berpengaruh terhadap penguasaan keterampilan yang lain. Dan sebelum proses belajar bicara terjadi, terdapat beberapa hal mendasar yang sangat penting yang harus diketahui, yaitu sebagai berikut:

1. Persiapan fisik untuk berbicara.

Kemampuan berbicara bergantung pada kematangan mekanisme berbicara. Ketika lahir, saluran suara anak masih sangat kecil, langit-langit mulut datar, dan lidah terlalu besar untuk saluran bicara. Sebelum semua sarana tersebut mencapai bentuk yang lebih matang, syaraf dan otot mekanisme berbicara tidak akan menghasilkan bunyi yang diperlukan bagi pembentukan kata-kata.

2. Kesiapan mental untuk berbicara.

Kesiapan mental untuk berbicara nergantung pada kematangan otak, khususnya bagian-bagian asosiasi otak. Biasanya kesiapan tersebut berkembang di antara umur 12 dan 18 bulan dan dalam pekembangan bicara disebut sebagai "saat dapat diajarkan".

3. Model yang baik untuk ditiru.

Model dibutuhkan seorang anak ketika dia belajar berbicara adalah karena ia membutuhkan rujukan apakah kata yang telah dibunyikannya adalah betul atau tidak. Model tersebut berasal dari lingkungan terdekatnya. Orangtua, pengasuh bayi, saudara, bahkan sampai pada penyiar televisi atau aktor dalam sebuah film. Jika anak kekurangan model yang baik atau adekuat, maka anak akan mengalami kesulitan belajar bicara dan hasil yang dicapainya pun akan berada di bawah rata-rata kemampuannya yang seharusnya.

4. Kesempatan untuk berpraktek.

Terdapat lingkungan yang menghilangkan kesempatan belajar berbicara pada anak. Hal ini akan menyebabkan anak kehilangan pula kesempatan untuk membuat orang lain mengerti akan apa yang dimaksudkannya atau 
diinginkannya, dan hal tersebut kemudian akan dapat membuatnya marah dan tidak termotivasi untuk belajar berbicara lagi.

5. Motivasi.

Jika anak mengetahu bahwa mereka dapat memperoleh apapun yang mereka inginkan tanpa memintanya dengan menggunakan bahasa bicara, dan jika pengganti bicara seperti tangis dan isyarat dapat mencapai tujuan tertentu, amak dorongan belajar bicara akan melemah. Lingkungan harus bekerjasama untuk menciptakan kondisi dimana, "mintalah dengan berbicara, maka akan kau dapatkan apa yang inginkan".

6. Bimbingan.

Cara yang paling baik untuk membimbing anak belajar berbicara adalah pertama, menyediakan model yang baik. Kedua, mengatakan kata-kata dengan perlahan dan cukup jelas sehingga anak dapat memahaminya, dan ketiga, memberikan bantuan mengikuti model tersebut dengan membetulkan setiap kesalahan yang mungkin dibuat anak dalam menirukan model tersebut.

Selain beberapa hal mendasar yang penting dalam proses belajar bicara yang disebutkan di atas, hal yang juga perlu diperhatikan adalah bahwa dengan tahapan belajar yang sama, kemampuan anak dalam berbahasa tidak sama antara satu anak dengan anak yang lain. Perbedaan-perbedaan tersebut antara lain dipengaruhi oleh beberapa kondisi (Hurlock, 1978: 186), yaitu:

1. Kesehatan: Anak yang sehat, lebih cepat belajar bahasa ketimbang anak yang tidak sehat, karena motivasinya lebih kuat untuk menjadi anggota kelompok social dan berkomunikasi dengan anggota kelompok tersebut.

2. Kecerdasan: Anak yang memiliki kecerdasan tinggi akan belajar bahasa lebih cepat dan memperlihatkan penguasaan bahasa yang lebih unggul ketimbanganak yang tingkat kecerdasannya rendah.

3. Keadaan sosial ekonomi: Anak dari kelompok yang keadaan sosial ekonominya tinggi akan lebih mudah belajar berbahasa, mengungkapkan dirnya lebih baik, dan lebih banyak berbicara ketimbang anak dari kelompok yang keadaan social ekonominya lebih rendah. Penyebab utamanya adalah bahwa anak dari kelompok yang lebih tinggi, lebih 
banyak didorong untuk berbicara dan mengenal bahasa dan lebih banyak dibimbing untuk melakukannya.

4. Jenis kelamin: Dibandingkan dengan anak perempuan, anak laki-laki lebih tertinggal dalam belajar berbicara dan mempelajari kosakata. Pada setiap jenjang umur, kalimat anak lelaki lebih pendek dan kurang betul tata bahasanya, kosa kata yang diucapkan lebih sedikit, dan pengucapannya kurang tepat ketimbang anak perempuan.

5. Keinginan berkomunikasi: Semakin kuat keinginan untuk berkomunikasi dengan orang lain, maka akan semakin kuat motivasi anak untuk belajar bahasa, dan ia akan semakin bersedia menyisihkan waktu dan mengeluarkan usaha yang lebih besar untuk belajar.

6. Dorongan: Semakin banyak anak didorong untuk berbicara mengenal kosakata dengan mengajaknya bicara dan didorong menanggapinya, maka akan semakin awal mereka belajar berbicara dan semakin baik kualitas bicaranya.

7. Ukuran keluarga: Anak tunggal atau anak dari keluarga kecil biasanya memiliki kemmapuan berbahasa lebih awal dan lebih baik ketimbang anak dari keluarga besar, karena orang tua dapat menyisihkan waktu yang lebih banyak untuk mengajar anaknya berbicara.

8. Urutan kelahiran: Dalam keluarga yang sama, anak pertama lebih unggul ketimbang anak yang lahir kemudian. Hal ini disebakan orang tua dapat menyisihkan waktunya yang lebih banyak untuk mengajar dan mendorong anak yang lahir pertama dalam belajar bahasa ketimbang untuk anak yang lahir kemudian.

9. Metode pelatihan anak: Anak-anak yang dilatih secara otoriter yang menekankan bahwa "anak harus dilihat dan bukan didengar" merupakan hambatan untuk belajar, sedangkan pelatihan yang memberikan keleluasaan dan demokratis akan mendorong anak untuk belajar.

10. Kelahiran kembar: Anak yang lahir kembar umumnya terlambat dalam perkembanganbahasa terutama karena mereka lebih banyak bergaul dengan saudara kembarnya dan hanya memahami logat khusus yang mereka miliki. Hal ini melemahkan motivasi mereka untuk belajar berbicara agar orang lain dapat memahami mereka. 
11. Hubungan dengan teman sebaya: Semakin banyak hubungan anak dengan teman sebyanya dan semakin besar keinginan mereka untuk diterima sebagai anggota kelompok sebaya, akan semakin kuat motivasi mereka untuk belajar bahasa.

12. Kepribadian: Anak yang dapat menyesuaikan diri dengan baik cenderung mempunyai kemampuan berahasa lebih baik, baik secara kuantitatif maupun secara kualitatif, ketimbang anak yang penyesuaian dirinya jelek. Kenyataannya, bicara seringkali dipandang sebagai salah satu petunjuk anak yang sehat mental.

\section{Mengenal Anak dengan Keterlambatan Bicara}

$S$ adalah anak yang terdiagnosa mengalami keterlambatan berbicara disebabkan kurang stimulasi usia dini serta kesalahan pola asuh. Saat ini, S duduk di TKA sebuah TK tri-lingual di kota Sidoarjo. Berdasarkan teori di atas diketahui bahwa keterlambatan bicara yang dialami oleh subjek antara lain disebabkan oleh beberapa hal yang bersifat eksternal, yaitu antara lain:

1) Stimulasi bahasa pada tahun-tahun awal kehidupan subjek. Yaitu dimana pada masa-masa awal kehidupannya, subjek telah mulai bergonta-ganti pengasuh, dengan pendekatan pengasuhan yang berbeda, dengan karakter pengasuh yang berbeda, dan dengan bahasa pengasuh yang berbeda karena pengasuh berasal dari berbagai daerah di Indonesia yang mana pengasuh tersebut merupakan para calon TKW magang yang bekerja untuk perusahaan tempat orangtua subjek bekerja. Para calon TKW tersebut telah dilatih bahasa Kantonis sebelumnya, sehingga di rumah subjek, yang merupakan tempat magangnya, mereka harus menggunakan bahasa tersebut, bercampur dengan bahasa ibu yang dimiliki oleh Subjek, bercampur dengan bahasa ibu dari pengasuh. Kata-kata pertama, seharusnya muncul pada usia 8 sampai 18 bulan. (Santrock: 2007: 358). Pada usianya, idealnya Subjek telah menguasai kemampuan bicara hampir seperti orang dewasa, dan kosa kata yang terucap sekitar 2.600 kata. (Papalia, dkk. 2009)

2) Kurangnya lingkungan yang memberinya kesempatan untuk belajar bahasa. Ayah subjek sangat protective dalam memperbolehkan subjek 
untuk bermain di luar rumah, dimana seharusnya kesempatan belajar berkomunikasi lebih besar di luar "pagar" rumah subjek. Di luar rumah, di kompleks tempat tinggal subjek, seharusnya subjek bisa berlatih berbicara dengan situasi sesungguhnya dengan anak-anak seusianya di kompleks tersebut, atau dengan orang-orang dewasa yang lain. Sikap ayah yang serba melarang dengan alasan kesehatan atau kekhawatiran efek negatif dari lingkungan luar rumah, membuat subjek semakin terkungkung dan belajar sebatas apa yang ada di dalam pagar rumah tempat tinggalnya.

3) Kurangnya dorongan bagi anak untuk menggunakan bahasa verbal dengan lebih baik. Ketika di rumah pun, subjek sedikit sekali mendapatkan dorongan untuk berbicara. Pengasuh-pengasuhnya lebih banyak diam selama mengasuh subjek, sekali berbicara, pengasuh tersebut menggunakan bahasa yang berbeda dengan bahasa ibu yang dimiliki oleh subjek. Orangtua pun mengaku tidak telaten mengajari secara perlahan kemampuan berbicara subjek sehingga dorongan untuk berbicara dengan lebih baik sangat kurang sekali. S seperti merasa sudah tidak bermasalah dengan caranya berbicara karena dengan berteriak saja semua keinginannya sudah terpenuhi.

4) Pola asuh yang diterapkan orangtua serta kondisi lingkungan yang menguatkan subjek untuk "tetap bahagia" dalam keterlambatan berbicaranya. Pengasuh subjek adalah seorang calon tenaga kerja magang yang tugasnya (dari orangtua) adalah melayani semua kebutuhan dan memberikan semua keinginan subjek, tanpa mendidiknya atau mengajarinya keterampilan berbicara. Sikap pengasuh yang serba membolehkan tanpa melakukan komunikasi verbal dengan subjek, menguatkan keterlambatan subjek dalam berbicara karena seperti dijelaskan di atas, dengan berteriak saja semua keinginannya sudah terpenuhi. Bahkan semakin subjek berteriak dan mengamuk, pengasuh akan semakin menurutinya karena takut dengan orangtua subjek. Hal tersebut tentu saja memperparah keterlambatan subjek dalam berkomunikasi secara verbal.

Untuk memahami permasalahan yang dihadapi oleh $S$ beserta kronologis penyebab keterlambatan berbicara yang dialaminya, dapat dilihat skema di bawah ini: 
Gambar 1: Skema Psikodinamika Subjek SCJ

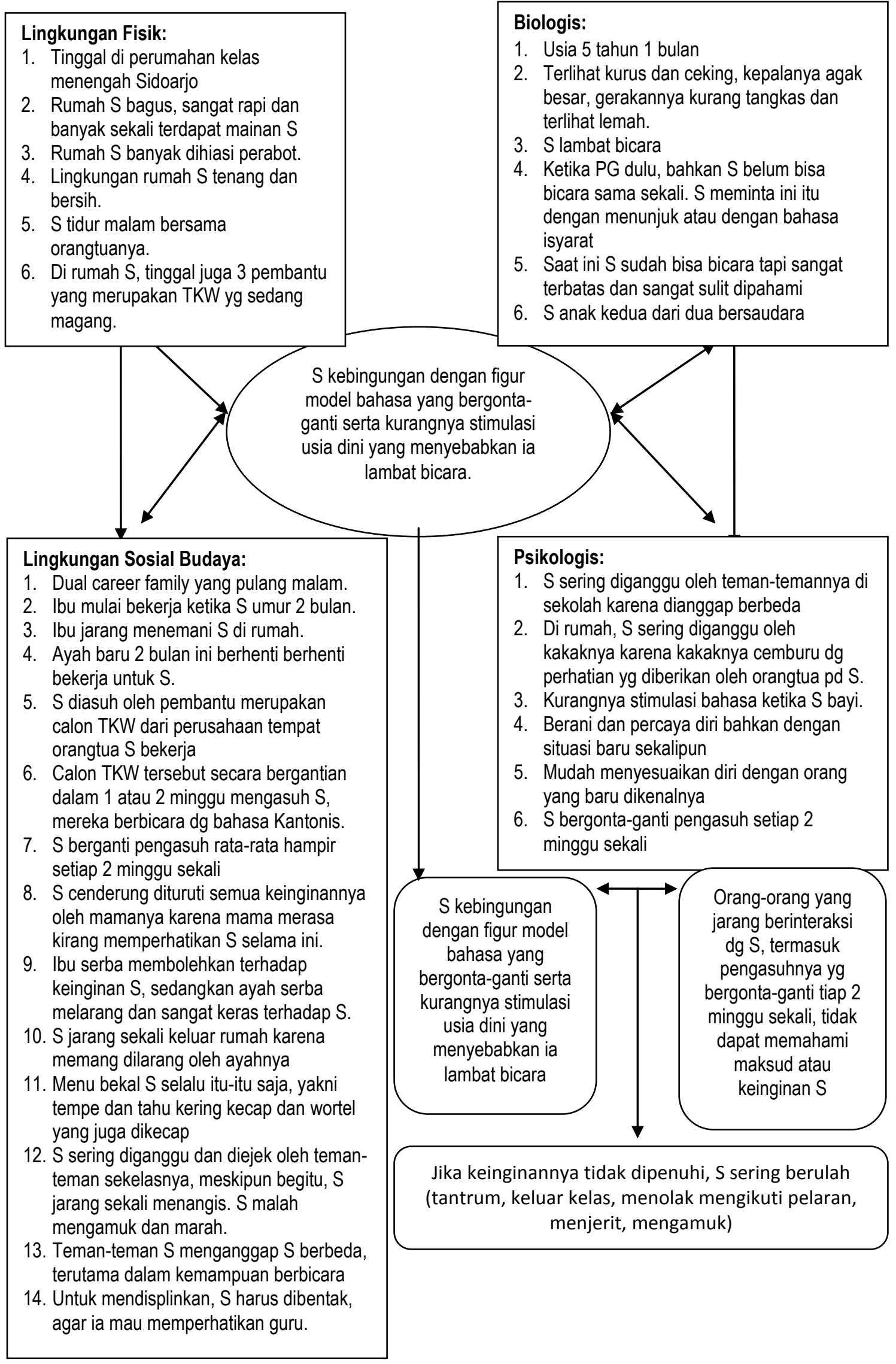




\section{Intervensi Psikologis Anak dengan Keterlambatan Berbicara}

Setelah dilakukan pemeriksaan mulai dari wawancara, observasi, tes DDTK, serta tes informal serta analisis dokumen, serta setelah ditemukannya permasalahan yang dihadapi oleh subjek, maka sangat perlu dilakukan sebuah intervensi untuk membantu subjek mengatasi keterlambatan perkembangannya, dalam hal ini keterlambatan berbicara, sebagai salah satu keterlambatan yang paling mencolok dan membutuhkan penanganan yang lebih dini. Adapun tujuan dilakukannya intervensi terhadap subjek dalam kasus ini adalah antara lain sebagai berikut:

1) Memberikan perubahan pemahaman orangtua subjek sehingga hal-hal berkenaan dengan pola asuh yang dapat memperparah kondisi kemampuan berbicara serta perilaku tantrum subjek dapat dikurangi atau bahkan dihilangkan sama sekali. Misalnya pola asuh yang serba membolehkan dari satu sisi yaitu ibu, serta pola asuh yang serba melarang dari sisi yang lain, yaitu ayah. Selain itu juga dibatasinya area bermain subjek dimana hal tersebut menyebabkannya kekurangan lingkungan belajar berkomunikasi verbal. Intinya, tujuannya adalah untuk merubah pandangan orangtua tentang pola asuh yang benar dan dapat membantu anak mereka mengatasi masalahnya.

2) Memberikan latihan terus-menerus kepada subjek agar ia semakin merasa termotivasi untuk berbicara dengan lebih baik tanpa mengamuk atau berteriak, sekaligus melatihnya mempelajari bagaimana kata-kata harus diucapkan dengan jelas agar orang lain mengerti dan dapat memahami keinginan atau maksud subjek.

3) Memberikan pengetahuan kepada pengasuh subjek untuk mengasuh subjek dengan lebih baik dan benar, terutama dalam hal berkomunikasis ecara verbal. Pengasuh dilibatkan dalam intervensi ini karena posisi pengasuh yang sangat penting dalam kehidupan subjek. 
Berdasarkan uraian permasalahan serta analisis teori di atas, kepada Subjek S dilakukan intervensi sebagai berikut:

Tabel 2: RANCANGAN INTERVENSI SUBJEK SCJ:

\begin{tabular}{|c|c|c|c|c|c|c|c|}
\hline & & & \\
\hline NO & METODE & SASARAN & TUJUAN & LANGKAH-LANGKAH & DURASI & MATERI & EVALUASI \\
\hline 1. & $\begin{array}{l}\text { Konseling } \\
\text { Keluarga }\end{array}$ & $\begin{array}{l}\text { Orang-tua } \\
\text { Subjek SCJ }\end{array}$ & $\begin{array}{l}\text { Memberika } \\
\mathrm{n} \text { informasi } \\
\text { kepada } \\
\text { orangtua } \\
\text { subjek } \\
\text { tentang } \\
\text { pola asuh } \\
\text { anak } \\
\text { dengan } \\
\text { keterlambat } \\
\text { an bicara }\end{array}$ & $\begin{array}{l}\text { 1. Membuka konseling dg } \\
\text { menyampaikan tujuan konseling } \\
\text { 2. Menyampaikan materi tentang pola } \\
\text { asuh yang tepat serta penanganan } \\
\text { anak lambat bicara } \\
\text { 3. Memberikan waktu untuk bertanya } \\
\text { jika ada hal yang ingin } \\
\text { didiskusikan lebih lanjut } \\
\text { Catatan: Konseling ini menggunakan } \\
\text { pendekatan TRE untuk } \\
\text { menghilangkan pandangan salah } \\
\text { orangtua tentang pengasuhan yang } \\
\text { over protective dan over permissif. }\end{array}$ & $1 \times 60^{\prime \prime}$ & $\begin{array}{l}\text { Materi tentang } \\
\text { pola asuh anak } \\
\text { dengan } \\
\text { keterlamba-tan } \\
\text { bicara. }\end{array}$ & $\begin{array}{l}\text { Observasi } \\
\text { dan } \\
\text { wawancara } \\
\text { ketika } \\
\text { konseling } \\
\text { keluarga } \\
\text { berlangsung, } \\
\text { serta hari- } \\
\text { hari } \\
\text { berikutnya } \\
\text { dalam sesi } \\
\text { intervensi S. }\end{array}$ \\
\hline 2. & $\begin{array}{l}\text { Latihan } \\
\text { bicara } \\
\text { dengan } \\
\text { lebih jelas } \\
\text { dan } \\
\text { dipahami } \\
\text { oleh orang } \\
\text { lain }\end{array}$ & Subjek SCJ & $\begin{array}{l}\text { Melatih } \\
\text { subjek } \\
\text { untuk dapat } \\
\text { melafalkan } \\
\text { kata secara } \\
\text { lebih jelas } \\
\text { dan } \\
\text { diphami } \\
\text { oleh orang } \\
\text { lain. }\end{array}$ & $\begin{array}{l}\text { 1. Tehnik modeling dalam bermain } \\
\text { sambil belajar: Sambil bermain, } \\
\text { setiap kali S mengucapkan kata } \\
\text { atau kalimat, terapis } \\
\text { mengkoreksinya, lalu meminta S } \\
\text { mengulangi dan menirukannya dg } \\
\text { benar. } \\
\text { 2. Belajar dengan gerak lagu: Terapis } \\
\text { memutar CD lagu anak-anak } \\
\text { berbahasa Indonesia yg sederhana, } \\
\text { lalu bersama-sama dg S menirukan } \\
\text { gerakan dan ucapan syair lagu. } \\
\text { 3. Flash Card: terapis menunjukkan }\end{array}$ & $6 \times 90^{\prime \prime}$ & $\begin{array}{l}\text { Flash card, CD } \\
\text { Akal Interaktif, } \\
\text { CD lagu anak. }\end{array}$ & $\begin{array}{l}\text { Observasi } \\
\text { dan } \\
\text { Wawancara, } \\
\text { serta tes lisan } \\
\text { secara } \\
\text { langsung }\end{array}$ \\
\hline
\end{tabular}




\begin{tabular}{|c|c|c|c|c|c|c|c|}
\hline & & & & $\begin{array}{l}\text { kartu bergambar kepada S sambil } \\
\text { membunyikan bunyinya. } S \\
\text { bertugas menirukan sambil melihat } \\
\text { gambar dan memperhatikan } \\
\text { gerakan bibir terapis. }\end{array}$ & & & \\
\hline 3. & $\begin{array}{l}\text { Pemberday } \\
\text { aan } \\
\text { Lingkungan }\end{array}$ & $\begin{array}{l}\text { Pengasuh } \\
\text { Subjek SCJ } \\
\text { di Rumah }\end{array}$ & $\begin{array}{l}\text { Memberika } \\
\mathrm{n} \text { informasi } \\
\text { tentang cara } \\
\text { pengasuhan } \\
\text { anak lambat } \\
\text { bicara } \\
\text { secara } \\
\text { benar }\end{array}$ & $\begin{array}{l}\text { 1. Membuka perbincangan nonformal } \\
\text { dengan pengasuh di sela-sela sesi } \\
\text { intervensi Subjek. } \\
\text { 2. Menjelaskan karakteristik pola } \\
\text { asuh anak lambat bicara. } \\
\text { 3. Memberikan contoh atau model } \\
\text { secara praktis pengasuhan dan } \\
\text { memberian panduan } \\
\text { pendampingan anak lambat bicara. } \\
\text { Terapis memberikan contoh lgsg } \\
\text { bagaimana memandu Subjek untuk } \\
\text { mengoreksi kata-kata atau } \\
\text { kalimatnya seperti dalam metode } \\
\text { intervensi pertama. }\end{array}$ & $3 \times 30^{\prime \prime}$ & $\begin{array}{l}\text { Essay tentang } \\
\text { pola asuh anak } \\
\text { dengan } \\
\text { keterlambatan } \\
\text { bicara }\end{array}$ & $\begin{array}{l}\text { Observasi } \\
\text { dan } \\
\text { wawancara } \\
\text { selama } \\
\text { pemberian } \\
\text { informasi } \\
\text { berlangsung, } \\
\text { serta hari- } \\
\text { hari } \\
\text { berikutnya } \\
\text { dalam sesi } \\
\text { intervensi S. }\end{array}$ \\
\hline
\end{tabular}




\section{E. Penutup}

Dari uraian diatas, untuk dapat mengatasi permasalahan anak dengan keterlampabatan bicara, dapat didekati dengan pendekatan sebagai berikut :

1. Ubahlah secara perlahan dan sedikit demi sedikit pola asuh yang selama ini diterapkan menjadi lebih ramah kepada anak, namun tetap memberikan batasbatas tertentu untuk memenuhi keinginan anak.

2. Dalam kemampuan bicara, anak membutuhkan model untuk dicontoh. Untuk melafalkan satu kata yang tepat dan mengkombinasikan dengan kata lain agar menjadi suatu kalimat yang berarti, anak membutuhkan contoh untuk ditiru. Contoh ini biasanya didengar dan orang-orang di sekitarnya seperti orangtua, teman, saudara atau tetangga maupun pembicara di TV yang sering dilihatnya lewat iklan. Teman sebaya biasanya memiliki pengaruh yang cukup besar. Anak-anak yang ditemukan mengalami gangguan kelambatan berbicara biasanya sedikit atau bahkan sama sekali tidak memiliki teman sebaya untuk bermain sehari-hari. Jadi, jadilah model yang dapat dicontoh anak, berbicaralah pelan-pelan dan jelas dengan anak. Didengar atau tidak, mau meniru atau tidak apapun yang kita lakukan terjemahkan dengan bahasa sehingga anak terbiasa mendengar bahasa yang kita ucapkan.

3. Berilah kesempatan dan motivasi untuk berlatih. Adanya perhatian dari lingkungan yang baik dan memberikan anak kesempatan, stimulasi yang memadai serta waktu untuk melatih keterampilan berbicaranya merupakan hal yang sangat menentukan tingkat keterampilan berbicara anak. Demikian pula jika anak menemukan kenyataan bahwa dengan bahasa isyarat, tangisan atau pengucapan sepatah kata saja, segala kebutuhannya dapat dimengerti dan sudah terpenuhi, maka motivasi anak untuk melatih dan meningkatkan keterampilan berbicaranya menjadi lemah.

4. Minimalkan jam menonton TV. Televisi memiliki pengaruh baik dan buruk bagi anak, tetapi apabila anak menonton TV sendirian lebih banyak pengaruh buruk yang diserapnya. TV akan maksimal pengaruh positifnya ketika anak menonton dengan didampingi orang dewasa yang akan menerjemahkan hal-hal yang tidak diketahuinya. Oleh karena itu minimalkan anak menonton TV, apalagi sendirian! 
5. Jangan bosan bicara dengannya. Berbicaralah secara perlahan dan jelas, jangan bosan-bosan untuk mengajaknya berbicara tiap saat dan mengulang kata-kata yang belum terampil diucapkannya. Usahakan kontak mata dengan anak ketika berbicara dan tetap bersikap santai. Koreksilah kesalahan ucapannya. Misalnya, "Ma, mumu", dorong anak untuk mengucapkan, "Mama, Adik minta minum".

6. Berikan reward. Puji dan hargailah setiap perkembangan atau keberhasilan anak sekecil apapun. Senyuman, tepuk tangan, acungan jempol atau dekapan hangat bila anak mampu mengucapkan kata dengan baik. Keterampilan berbicara adalah seperti keterampilan naik sepeda, makin sering kita melatihnya meskipun harus jatuh bangun bahkan kaki anak sampai lecet-lecet, anak tetapi jika kita memberinya memotivasi dan kesempatan maka anak akan lebih cepat terampil.

\section{F. Daftar Pustaka}

Andriany. L. (2009). Pengaruh Stimuli Terhadap Pemerolehan Bahasa Anak Prasekolah. Linguistik Indonesia Tahun ke 27, No 1. Universitas Islam Sumatera Utara.

Baumrind, D. (1971). Current patterns of parental authority. Developmental Psychology Monograph, 4 (1, Pt. 2).

Baumrind, D. (1978). Parental disciplinary patterns and social competence in children. Youth and Society. 9. 239-276

Chaplin J.P. (2005). Kamus Lengkap Psikologi. Jakarta: Rajagrafindo Persada.

Corey, G. (2005). Teori dan Praktek: Konseling \& Psikoterapi. Bandung: Refika Aditama.

Darling, N. \& Steinberg, L. (1993). Parenting Style as Context: An integrative model. Psychological Bulletin, 113(3), 487-496.

Hurlock, E. (1978). Perkembangan Anak. Jakarta: Erlangga.

Neill, A.S. (1960). Summerhill: A Radical Approach to Child Rearing. New York: Hart Publishing.

Papalia, dkk. (2009). Human Development. Jakarta: Salemba Humanika.

Santrock, J. W. (2007). Perkembangan Anak. Jakarta: Erlangga.

Slavin, E. R. (2008). Psikologi Pendidikan: Teori dan Praktek. Jakarta: Indeks.

Sumarlin H. I. (2001). Perkembangan Bahasa. Surabaya: Universitas Airlangga. Readcast. TM.

Syah, M. (2005). Psikologi Pendidikan. Bandung: PT Remaja Rosdakarya.

Walgito, B. (1993). Pengantar Psikologi Umum. Yogyakarta: Andi Offset. 